\title{
Corporate Culture and Organizational Change- a Study on a Large Pharmaceutical Company in Bangladesh
}

\author{
S.M. Rezaul Ahsan
}

Senior Manager, Organization Development, The ACME Laboratories Ltd, Dhaka, BANGLADESH

\begin{abstract}
This paper investigates the relationship between corporate culture and attitudes toward organizational change from the perspectives of a large pharmaceutical company in Bangladesh. A structured questionnaire was developed on the basis of the competing values framework of culture typology of Cameron and Quinn (2006) and a study of Justina Simon (June 2012), which was distributed to the 55 staff members of the company. The result shows that there is a significant relationship between corporate culture and organizational change. The study reveals that the organization has adopted all four types of organizational culture and the dominant existing organizational culture is the hierarchy culture. The study also shows that the resistance to change is a function of organizational culture. The implications of the study are also discussed.
\end{abstract}

Key Words: Organizational Culture, Organizational Change, Resistance to change, Change Management

\section{INTRODUCTION}

Corporate culture is a popular and versatile concept in the field of organizational behavior and has been identified as an influential factor affecting the success and failure of organizational change efforts. Culture can both help and hinder the change process; be both a blessing and a curse when it comes to successfully undergo change. An organization is believed to be a cluster of many elements; of which organization culture is considered the core part which play a vital role on organizational changes and innovations. The Bangladeshi pharmaceutical industry has low capital intensity, but requires high skills with immense need for sophisticated technologies. For these reasons, the entry barriers to the industry are low and therefore, continued innovation and change is a must to cope up with the increasing competition in the market place. Organizational change and innovation play a major role in this dynamic business environment. New products cannot be developed and new services cannot be introduced without changing the process of production or the way of delivering services to customers. Literally, to improve people, processes, services or products, change is essentially required. Customers' preferences and tastes are increasingly changing and this has become a question of what the organization can offer better than its competitors (Simon, 2012). Therefore, fostering change efforts to the continual improvement has become a prerequisite for any organization. Nacinovic, Galetic and Cavlek (2009:398) also noted that 'organizational change and innovation have become an absolute necessity to perform well under the present condition of rapid external and internal development and changes'. Thus, this study aims to investigate the impact of organizational culture on organizational change.

There has been significant research in the literature to explore the impact of organizational culture on organizational change. For instance, Scholars (Goetsch and Davis, 2010; Cummings and Worley, 2009; Shah and Irani, 2010; Rashid, 2004; Cameron and Quinn, 2006; Rahman, 2002; Jackson and Philip, 2005; Schein, 2009; Robbins, 2005) claim that organizational culture influences organizational change. In the recent study, Uddin, Luva and Hossian (2013) report that corporate culture has significant impact on employee performance and productivity of Telecommunication sector in Bangladesh. On the other hand, Islam, Ahmed and Hasan (2011) establish that there is a relationship between organizational culture and knowledge sharing in the service organization of Bangladesh. Kazi (2009) finds that managerial decision making is influenced by national and organizational culture in Bangladesh, India and Finland. Notwithstanding the organizational culture and its influence on employee performance, productivity, innovation etc have been studied over the past decades and considered as an immersed topic for achieving organizational excellences, there is no empirical research conducted on the effects of organizational culture on organizational change particularly from the perspectives of an emerging sector like Pharmaceuticals in Bangladesh. This research will try to bridge such a gap aiming to examine the impacts of organizational culture on organizational change in the context of pharmaceutical company of Bangladesh. 


\section{ObJectives OF the Study}

The objectives of the study are to realize the impact of corporate culture on organizational change, the most dominant culture type in the organization and the basis for the resistance to the change in context of Pharmaceutical Company in Bangladesh.

\section{LITERATURE REVIEW}

\section{Corporate/Organizational culture}

Organizational culture is conceptualized as shared beliefs and values within the organization that helps to shape the behavior patterns of employees (Kotter and Heskett, 1992). Gordon and Cummins (1979) define organization culture as the drive that recognizes the efforts and contributions of the organizational members and provides holistic understanding of what and how is to be achieved, how goals are interrelated, and how each employee could attain goals. Thus, the organizational culture is the means of keeping employees in line and exhilarating them towards organizational objectives. Corporate culture is a very powerful force that resides within every organization, and it has many powerful attractions as a lever for change, and these forces are powerful because they operate outside of organization's awareness (Schein, 2010:7). Aiman-Smith (2004:1) supports Schein's declaration by mentioning that 'culture is indeed a powerful set of forces that determine human behavior', and is known for defining people's behavior and how organizations get things done either in positive or negative ways. Johnson et al. (2006:47) defined organizational culture as 'the basic assumptions, imbedded values, beliefs, philosophies, attitudes and operating norms that are shared by members of the organization'. Culture is a distinctive competence and sense of identity, it is the glue that holds the organization together, it helps the organization to strive towards integration and clarity, and put heavy emphasis on socialisation (Mannion, 2010:33). Robbins et al. (2009:434) reported that corporate culture can give an organization a competitive advantage over other organizations. Robbins et al (2009:427) stated that 'culture communicate a sense of identity to organizational members, facilitates commitment to something larger than individual selfinterest, enhances social system stability, and serves as a meaningful control mechanism that guides and shapes the attitudes and behavior of employees'. There is an observation from Ojo (2009:391) that organizational culture provides a powerful mechanism for controlling behavior by influencing how people attach meaning to their world and how people interpret events.

Cameron and Quinn (2006) did an excellent job of laying out how to diagnose and change organizational culture. Importantly, they also provided methods and rationale on measuring culture given the competing values framework. Their Competing Values Framework combines two cultural dimensions, creating a $2 \times 2$ matrix with four clusters. Graphically, one dimension can be drawn vertically and the other drawn horizontally-resulting in a two-by-two figure with four quadrants (shown in Fig 1). These two dimensions are comprised of two pairs of competing values held by organizations, i.e. flexibility and discretion vs. stability and control, and internal focus and integration vs. external focus and differentiation. One dimension differentiates the effectiveness of the organizations according to their emphasis on the flexibility and stability. In other words, this dimension describes how the processes are carried out within the organization. This means that while some organizations found their effectiveness on their ability to be flexible and adaptable to change, others are effective by being stable. The other dimension differentiates the organizations' effectiveness based on the internal and external focus. This dimension implies that some organizations are viewed as effective by focusing on their internal processes, while others are effective when they focus externally to compete with other organizations. Based on the two dimensions, Cameron and Quinn categorized organizational culture into four main cultural types, i.e. clan, adhocracy, hierarchy and market.

Fig 1: Competing Values Framework

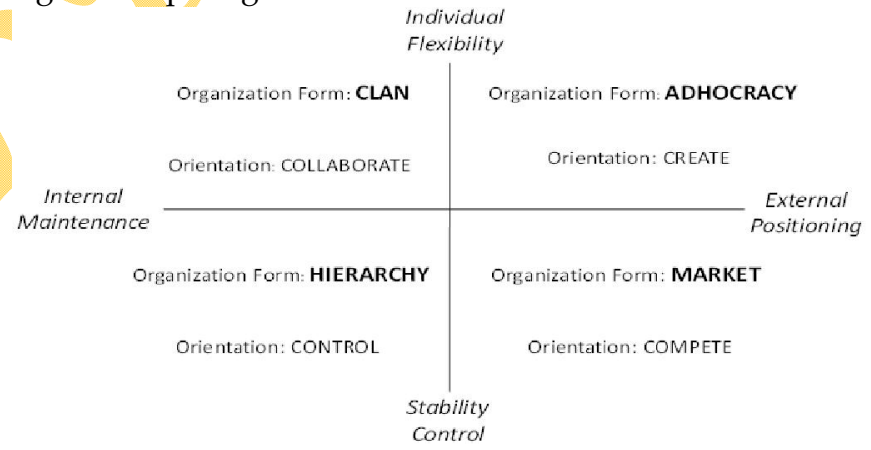

\section{Clan Culture}

Businesses displaying the clan culture strongly emphasize internal collaboration. Acting more like a family than a structured corporation, companies with this type of culture are concerned with teamwork and morale, and Kinicki determined that this culture type produced the highest level of employee satisfaction. Clan corporations typically have a flat internal structure, led by a single leader or owner who acts as a paternalistic or mentoring influence. This culture strongly emphasizes loyalty, a companywide shared vision and goals, and ongoing employee development.

\section{Adhocracy culture}

The adhocracy culture places most importance on flexibility and innovation. Adaptability and quick reactions to the changing market, competition and external environment is an integral component of corporate strategy in this type of business. Leadership in an adhocracy culture is demonstrated by 
entrepreneurship and risk taking. The emphasis is always on growth opportunities and employees are encouraged to experiment with new ideas. What might seem like chaos and disorder to the hierarchy culture is valued and embraced in the fast-moving adhocracy culture.

\section{Hierarchy culture}

A business that adheres to formal rules, regulations and bureaucracy is demonstrating a hierarchy culture. This type of company typically has several traditional layers of management, and emphasis is placed on following the chain of command. Power, status and position help the leaders within a hierarchy culture manage their employees, and organized, efficient operations are a central part of the organization's strategy and mission. It is prevalent among government organizations and large companies, and many businesses demonstrate at least some elements of the hierarchy culture in day-to-day operations.

\section{Market culture}

The market culture gained popularity among businesses in the 1960s. This culture is similar to the hierarchy culture in its emphasis on organization and control. However, the market culture places great value on the external relationships with customers, suppliers and creditors, for example, believing that successful relationships will increase the company's competitiveness. According to ongoing studies conducted by Angelo Kinicki and his colleagues at the W. P. Carey School of Business at Arizona State University, the market culture is the culture type most likely to yield the best financial results.

Cameron and Quinn (2006:34) indicate that organizations that accomplish their effectiveness and competitiveness transpiring from their ability to adapt and change are those that put emphasis on flexibility, discretion and dynamism. It can therefore be summarized that for an organization to be effective, it should adopt the combination of these four cultural types.

\section{Organizational Change}

Organizational change is a structured approach in an organization for ensuring that changes are smoothly and successfully implemented to achieve lasting benefits. Globalization and the constant innovation of technology result in a constantly evolving business environment. Therefore, the ability to manage and adapt to organizational change is an essential skill required in the workplace today. Organizational change is a process that organizations pursue to align their core business aspects in order to be flexible enough to anticipate, adapt and respond to demanding global trends (Dawson, 2003). Change management is an approach to shift or transform individuals, teams, processes or entire organization from a current state to a desired future state through influencing the change stakeholders to accept and embrace changes at their concern in order to get advantage and avoid distractions. Organizational change can be viewed as an organization's response to significant pressures and forces arising from an internal and external environment in order to increase value and improve corporate effectiveness. Mills, Dye and Mills (2008:4) support these claims by defining organizational change as an alteration of core aspects of organization operations. These core aspects of an organization includes: structure, technology, culture, leadership, goals and workforce of an organization. Lemmex (2007) describes organizational change as a process an organization follows when moving away from its current position to a desired state. Porras and Silvers' definition of organizational change as cited in Van Tonder (2004) states that organizational change is an initiative which alters critical organizational processes, which in turn influences individual behaviors that subsequently impact on organizational outcomes.

On the other hand, Joseph Juran definition as cited in Goetsch and Davis (2010:123) describes organizational change as a 'clash between cultures', and this usually develops when an organization solves its problems. Brown and Harvey (2006) agree with this statement by stating that solving organizational problems usually involves the introduction of change. Brown and Harvey (2006) further assert that organizational change affects the organization and its members because it is one of the managers' most difficult tasks to initiate. Cummings and Worley (2009:183) validate these claims by indicating that change is indeed a difficult task to initiate because 'change demands new knowledge and skills, attitudes and behaviors from organization members'.

In order to produce the desired results in the organizational change efforts, attention should be paid to managing the human aspect of an organization by completely identifying factors influencing individuals' attitudes towards change (Simon, 2012). Barclay (2009:1) notes that most researches have proved that, for change to be effective, change efforts should be focused on the people because an organization after all, is just a collection of people working towards a common goal. The success of change initiatives, however, depends on the level of commitment and support from employees and management of the organizations. All change processes in an organization are undergone by the following change formula.

$\mathrm{C}=\mathrm{D} \times \mathrm{V} \times \mathrm{F}>\mathrm{R}$

Here $\mathrm{D}$ stands for dissatisfaction with current state, $\mathrm{V}$ stands for vision of the change, $\mathrm{F}$ stands for first action to the change and $R$ is the resistant to the change which depends on the culture. It is useful to use Chris Argyris's intervention theory in applying the change formula. The theory suggests that the more people you get involved (related to organization culture) in diagnosing the situation, exploring options, and shaping a picture for the future, the more likely you are to develop a commitment in people that is sustainable under pressure and over time.

The power of organization culture in the organizational change has been underestimated by many. Borrowing Mckinsey 7S model as cited in Kaplan (2005) and Lynch 
(2000), many organizations have failed to implement change initiatives effectively because they concentrate much on the hard elements, i.e. structures, systems and strategies, and ignore or pay too little attention to the soft elements, i.e. skills, staff, management style and shared values. Therefore, the literature reveals that corporate culture is one of the factors influencing the success and failure of organizational change efforts. This exposure is being supported by many studies. Shah and Irani (2010:2) indicate that organizational culture is reportedly one of many predictors for the success of organizational change programs. One of the major findings from a study conducted by Rashid, Sambasivan and Rahman in 2004 on the influence of organizational culture on attitudes towards organizational change in Malaysia proves that organizational culture has an effect in the organizational change process (Rashid et al. 2004:176). Rashid et al (2004:168) moreover, report that organizational culture has also been recognized to have an important role in assuring efforts in organizational change. Similarly, Cameron and Quinn (2006:1) testify that empirical researches have reported that the most frequently cited reason given for change efforts failure was a neglect of organizational culture. Cameron and Quinn (2006:5) further report that most scholars and observers also acknowledged that an organizational culture has a powerful effect on performance and long-term effectiveness of the organization. Correspondingly, a study by Rahman in 2002 found that there is an association between organizational culture and attitudes towards organizational change (Rahman, 2002: iii). Furthermore, Latta (2009:19) indicates that organizational culture is one of many situational variables that have consistently emerged as a critical factor in determining the leaders' capability to implement change efforts. According to Jackson and Philip (2005:1), organizational culture is now widely acknowledged as one of the major obstacles to managing change. Schein (2009:6) reveals that cultural issues influence all aspects of how an organization functions. Robbins (2005:602) claims that culture can be a liability to an organization when it creates barriers to change, diversity or to mergers and acquisitions.

In addition, Brown and Harvey (2006:445) report that corporate culture can be a force in reinforcing or resisting strategic changes. Saran et al. (2009:12) note that change implementation process changes operations, procedures and systems and these aspects are clearly found to be connected to the organizational culture. Saran et al. (2009:12) further point out that by creating a connection between organizational culture and change does not only facilitate effective change implementation, but also embed change in the day-to-day life of the organization. It is found that different types of organizational culture have different levels of acceptance of organizational change (Rahman, 2002; Rashid et al, 2004). For this reason, organizational change requires a culture that supports change initiatives.
From the literature review provided, it is evident that for an organizational change to take place, it will depend on the corporate culture adopted by the organization. Corporate culture has an influence on the organization's response to change, and different types of organizational culture have different levels of acceptance of organizational change. This research, therefore, focuses on deducing a link between corporate culture type and organizational change within the culture typology based on competing values framework developed by Cameron and Quinn. In this study, corporate culture is independent variable while organizational change is dependent variable.

\section{HyPOTHESIS/ RESEARCH QUESTIONS}

Within the theoretical framework of the study, this research seeks responses to the following questions:

- Is there a significant relationship between corporate culture and organizational change of ACME Pharmaceuticals?

- What is the most dominant culture type at the organization in terms of Clan, Adhocracy, Hierarchy and Market types?

- Is resistance to change a function of organizational culture?

\section{ReseARCh Design \& Methodology}

\section{Research Approach \& Methodology}

In this study, a survey method under quantitative research design has been applied for data collection and analysis. This approach is viewed as the most suited methodology for gathering information from the staff members regarding their perceptions towards organizational culture and their feelings, observation, and experiences about change. Besides, a survey method can be the best choice for collecting data in terms of efficiency, because this method can be administered in a more convenient and economical way. A quantitative research design was adopted in this study because it aimed clearly and precisely at determining the relationship between an independent variable and other dependent variables under investigation (Welman et al., 2005). Shah (2009:92) indicates that a quantitative approach is one of the major approaches applied in business and social sciences research methodology. To remove the biasness and conflict of interest, the quantitative approach is the best choice for the researcher for gathering and presenting data perfectly.

\section{Population representation}

A population is any precisely defined group of people, events or things that are of interest to and under investigation by the researcher and from which the sampling elements are drawn (Van Stuyvesant Meijen, 2007:77). In this research, the total population is made up of the total staff working in the Factory and Corporate Office of ACME. To make the study rational, the actual sampling frame was limited to the back office staff (i.e. 
Factory and Corporate Office) of the company as these people play the key role to implement any change initiative and represent a group or function under organizational hierarchy. This selection was also based on practical considerations such as respondent's competence to capture questionnaires, researcher's ease of access to the respondents and respondent's involvement to the change.

\section{Sampling Method}

A sample is a subset and representation of the population that is selected for research, and it consists of a selection of members from the population (Bryman and Bell, 2007: 182). The sample was consisted of 55 individual staff members who serve as permanent staff and involve in the day to day operations as well as change. The sample was selected in a stratified random manner whereby staff members were segregated into strata such as: nonmanagement, mid-management and senior management. Cooper \& Schindler (2003:193) and Welman et al. (2005:61) report that stratified sampling gives every member from each separate stratum a chance to be included in the sample. From each separate stratum, a random sampling technique was used to select a total of 55 staff members that constituted the sample size.

A total of 55 questionnaires were administered, 45 questionnaires were returned to the researcher which constituted a return rate of $81.82 \%$. However, out of the 45 questionnaires returned $40 \quad(72.73 \%)$ were correctly completed while $5(9.09 \%)$ questionnaires were incorrectly completed. The incorrectly completed questionnaires were treated as unusable. So, only 40 (72.73\%) questionnaires were used in this study.

\section{Research instrument}

Four parts of structured questionnaires were used to obtain responses from the respondents. The first part comprises demographic characteristics of respondents, enquiring information about respondents' personal attributes such as gender, age, and highest academic qualification, number of years of working at the company, job category, and the division or department or section where the respondent was working. The second part measured respondents' perceptions towards organizational culture using an Organizational Culture Assessment Instrument (OCAI) based on the Competing Values Framework by Cameron and Quinn (2006). This was solely aimed to identify the dominant culture types that exist in ACME in terms of the Clan culture, Adhocracy culture, Market culture, and Hierarchy culture. The third part of the questionnaire was designed to acquire information on the perception of respondents to change. This section as also requested respondents to indicate their agreement or disagreement with the statements on a 5-point scale ranging from strongly disagree (1) to strongly agree (5). The fourth part of the questionnaire consisted of two open-ended questions which were designed for participants to give additional information and recommendations related to the topic.

\section{RESULTS \& DISCUSSION}

\section{Organizational culture profile}

The results of the Organizational Culture Assessment Instrument (OCAI) were calculated based on the Competing Values Framework, suggested by Cameron and Quinn (2006). The perceived dominant existing organizational culture based on the view of respondents is shown in the Table 1 . The average scores of individual items of OCAI are also shown in the Table 2.

Table 1 Average Scores of the Perceived Dominant Organizational Culture

\begin{tabular}{|l|l|}
\hline Clan & 19.19 \\
\hline Adhocracy & 20.94 \\
\hline Hierarchy & 33.59 \\
\hline Market & 26.28 \\
\hline
\end{tabular}

Table 2 Average Scores of the Individual Items of OCAI

\begin{tabular}{|c|c|c|c|c|c|c|}
\hline Culture Type & $\begin{array}{l}\text { Organizational } \\
\text { Characteristics }\end{array}$ & $\begin{array}{l}\text { Organizational } \\
\text { Leadership }\end{array}$ & "Cohesion & $\begin{array}{l}\text { Management } \\
\text { of Staff }\end{array}$ & $\begin{array}{l}\text { Strategic } \\
\text { Emphasis }\end{array}$ & $\begin{array}{l}\text { Reward } \\
\text { System }\end{array}$ \\
\hline$\overline{\text { Clan }}$ & 21.50 & 20.30 & 19.23 & 16.48 & 18.06 & 19.56 \\
\hline Adhocracy & 21.20 & 21.74 & 22.75 & 20.75 & 19.85 & 19.37 \\
\hline Hierarchy & 32.14 & 33.45 & 30.65 & 35.57 & 33.08 & 36.62 \\
\hline Market & 25.16 & 24.51 & 27.37 & 27.20 & 29.01 & 24.45 \\
\hline
\end{tabular}

\section{Cultural profile for staff category}

The culture profiles of respondents in different staff categories are presented in Table 3.

Table 3 Average Scores of the Perceived Dominant Organizational Culture of Staff Category

\begin{tabular}{cccc}
\hline \hline Culture Type & Non-management & Mid-management & Top-management \\
\hline Clan & 18.26 & 17.14 & 25.13 \\
Adhocracy & 21.50 & 23.62 & 26.57 \\
Hierarchy & 33.65 & 32.08 & 20.21 \\
Market & 26.59 & 27.16 & 28.09 \\
\hline \hline
\end{tabular}




\section{Perception towards organizational change}

This has been done on the basis of Likert scale of 1 (strongly disagree) to 5 (strongly agree). In this section, the data were analyzed to get respondent's perception whether they accepted or rejected the statement mentioned in the instrument. Respondents who scored 1 and 2 were considered together to indicate disagreements. Table 4 Employees' Perceptions towards Change Efforts

\begin{tabular}{|c|c|c|c|c|}
\hline Concern & Disagree & Neutral & Agree & $\begin{array}{l}\text { Total } \\
\text { Respondent }\end{array}$ \\
\hline I find change initiatives necessary & 25 & 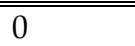 & 35 & 40 \\
\hline I see change initiatives as opportunities rather than threats & 10 & 5 & 25 & 40 \\
\hline I look forward to changes within my workplace & 10 & 0 & 30 & 40 \\
\hline I am involved in all aspects of changes that affect me & 12 & 1 & 27 & 40 \\
\hline Changes have clear benefits both for me and my company & 3 & 2 & 35 & 40 \\
\hline I find change initiatives not appropriate and necessary & 33 & 1 & 6 & 40 \\
\hline Change is a painful process with no positive results & 38 & 0 & 2 & 40 \\
\hline I do not see benefits and advantages which changes bring & 30 & 0 & 10 & 40 \\
\hline When a change effort is initiated, I definitely disagree & 38 & 0 & 2 & 40 \\
\hline I fear losing my status, power or my job because of change & 15 & 3 & 22 & 40 \\
\hline Changes interrupt the way I do things around here & 30 & 2 & 8 & 40 \\
\hline I cannot adapt easily to new ways of doing things & 29 & 1 & 10 & 40 \\
\hline I prefer work that is familiar and within my comfort zone & 30 & 3 & 7 & 40 \\
\hline I have negative experiences with previous changes & 25 & 0 & 15 & 40 \\
\hline
\end{tabular}

Relationship between Organizational Culture and the number of respondents who had positive or negative Change To establish the relationship between different types of the Table 5 .

organizational culture and perception towards change,

Table 5 Perception towards Change According to the Four Culture Category

\begin{tabular}{cccc}
\hline \hline Culture Type & $\begin{array}{c}\text { Perception towards } \\
\text { change }\end{array}$ & Frequency & Percentage \\
\hline \hline \multirow{3}{*}{ Clan } & Positive & 13 & 86.67 \\
& Neutral & 0 & 0 \\
Negative & 2 & 13.33 \\
Adhocracy & Positive & 14 & 82.35 \\
& Neutral & 0 & 0 \\
Negative & 3 & 17.65 \\
Hierarchy & Positive & 22 & 57.89 \\
& Neutral & 2 & 5.26 \\
& Negative & 14 & 36.85 \\
Market & Positive & 20 & 66.67 \\
& Neutral & 1 & 3.33 \\
\hline \hline
\end{tabular}

\section{Discussions}

To study the relationship between organizational culture and organizational change, the perception towards organizational culture and the perception towards change were correlated. This showed that (Table 5) the Clan culture of $86.67 \%$ had a positive perception towards change. In the Adhocracy culture $82.35 \%$ had a positive perception towards change. In the Hierarchy culture $57.89 \%$ had a positive perception towards change. In the Market culture $66.67 \%$ had a positive perception towards change. This means that a Hierarchy
Respondents having scored 3 were regarded as neither in agreement nor disagreement, thus treated as being neutral. Respondents who scored 4 and 5 were considered together to indicate agreements. The results are presented below according to sections as indicated in the research instrument. or neutral perceptions have been analyzed and shown in

culture is less receptive to change than other culture types. The findings thus showed that organizational culture plays an important role in the change process. Therefore, it can be concluded that there is a relationship between corporate culture and organizational change of ACME.

The analysis (Table 1) showed that Hierarchy culture has the highest average score of 33.59 followed by Market with an average score of 26.28, then Adhocracy with an average score of 20.94, while Clan culture has the lowest average score of 19.19. It is obvious that the dominant culture of ACME is 
Hierarchy. The average scores of individual items of OCAI shown in the Table 2 also indicated that the most dominant culture in the company is Hierarchy. This is also evident in the Table 3 of staff category, except the slightly inconsistency in Hierarchy type of Top-management's view as they usually sponsor change initiatives. According to Cameron and Quinn (2006:67), an organization possessing the hierarchy culture 'focuses on internal maintenance with the need for stability and control'. The second dominant culture of the company is the Market. Cameron and Quinn (2006:67) indicate that an organization possessing the market culture 'focuses on external positioning with the need for stability and control'. The third dominant culture is Adhocracy. An adhocracy culture focuses on external positioning with a high degree of flexibility and individuality (Cameron and Quinn, 2006:67). The organization with this type of culture organization is usually dynamic, entrepreneurial and a creative place to work; people value innovation, experimentation, and developing new products and services. The least dominant culture of ACME is Clan. Cameron and Quinn (2006:67) indicates that an organization possessing the clan culture focuses on internal maintenance with flexibility, concern for people, and sensitivity to customers.

To establish how respondents in each culture type associate with resistance to change, the responses in each culture type were linked and found that $18 \%$ of respondents in the Clan culture are associated with resistance to change. In the Adhocracy culture, $14 \%$ of respondents are associated with resistance to change. In the Hierarchy culture, $38 \%$ of respondents are associated with resistance to change. In the Market culture, $25 \%$ of respondents are associated with resistance to change. The results can be interpreted that respondents in the Hierarchy culture are more resistant to change. The results on the Vision for change showed that $52 \%$ of respondents in the Clan culture felt that the reasons, benefits and urgency are properly communicated to employees. The majority $(79 \%)$ of respondents in the Adhocracy culture felt that the reasons, benefits and urgency for change are properly communicated. In the Hierarchy culture, only $28 \%$ of respondents agreed. In the Market culture, $38 \%$ of respondents agreed. It can, therefore, be concluded that resistance to change can be a function of organizational culture.

\section{CONCLUSION \& RECOMMENDATION}

The results showed that the dominant culture of ACME is Hierarchy, and there is a relationship between corporate culture and organizational change. The results also revealed that resistance to change is a function of organizational culture. By showing the relationship between organizational culture and change, this study supports other empirical studies in this field (e.g. Goetsch and Davis, 2010; Cummings and Worley, 2009; Shah and Irani, 2010; Rashid, 2004; Cameron and Quinn, 2006; Rahman, 2002; Jackson and Philip, 2005; Schein, 2009; Robbins, 2005), particularly the study conducted by Justina Simon (2012) whose work has been perused in preparing the research instrument in addition to the study of Cameron and Quinn. The findings of this study will have practical implications for the scholars, organizations within the industry and other organizations within and out of the country to improve organizational culture for adapting changes to the innovation and excellence. With reference to the issues learned from the research findings, the researcher has recommended to adopt the Adhocracy culture type as the most dominant culture of the company for continual improvement to the excellence through changes and innovations. This can be achieved if the company establishes a more flexible organizational structure rather than a hierarchical structure. As change is fostered by the leaders they should invest their commitment in providing leadership and support during the change implementation process. Inherently, human beings are resistant to change, therefore communicating and educating employees about the change in advance can be helpful to reduce resistance and at the same time encourage employees' commitment to change and improve change management skills. Furthermore, organizations should reward the employees who are involved with the change to make it successful. Employees should be treated as one of the valuable and indispensable resources of the organization.

Although this study was conducted in a single company, it is anticipated that the findings may have relevance on a broader scale and further research can be carried out on the same topic in order to include a large sample of the population. Further study may also be conducted to reveal the link of corporate culture with other variables like organizational commitment, organizational performance, employee productivity, organizational effectiveness etc. By replicating this study in different countries and contexts the results could be very helpful for developing an effective corporate culture.

\section{REFERENCES}

[1] Aiman-Smith L. (2004). Short summary: What Do We Know about Organisational Culture.

[2] ACME Laboratories Ltd. (2013). Annual Report. Dhaka, Bangladesh.

[3] Baclay, A. (2009) Employee change agent: The foundation of effective organisational change International Business Research Journal, vol.2, No. 4.

[4] Bryman, A., and Bell, E. 2007. Business Research Methods. $2^{\text {nd }}$ Edition. New York: Oxford University Press.

[5] Calisir, M. (2008). Organizing Corporate Culture: A case study of a Turkish software organisation. A Thesis submitted to the Graduate School of Social Sciences, Middle East Technical University.

[6] Cameron, K. S. and Quinn, R. E. (2006). Diagnosing and changing organisational culture. Based on the Competing Value Framework. Revised edition, San Francisco. JosseyBass Publishers.

[7] Cooper, D. R. and Schindler, P. S. (2003). Business Research Methods. $8^{\text {th }}$ Edition, New York. McGraw-Hill.

[8] Cummings, T. G. and Worley, C. G. (2009) Organisation development and change, $9^{\text {th }}$ Edition, Mason, OH. SouthWestern Cengage Learning. 
[9] Daft, R. (2006). Organisation Theory and Design: Understanding the Theory and Design of Organisations. International Student Edition. Mason, OH. South-Western Cengage Learning. Dailey, R. (2008). Organisational Behaviour. Edinburgh Business School.

[10] Dawson, P. (2003). Reshaping Change: A Processual Perspective (Understanding Organisational Change), New York. Routledge.

[11] Gilley, A., Godek, M. and Gilley, J. W. (2009). Change, resistance, and the organisational immune system. Society for the Advancement of Management. Advanced Management Journal, vol. 74, no. 4, pp. 4-12.

[12] Goetsch, D.L. and Davis, S.B. Quality Management for Organisational Excellence, $6^{\text {th }}$ Edition

[13] Gordon G., \& Cummins W. (1979). Managing management climate. Toronto, Canada, Lexington Books, International Edition, New Jersey. Pearson Prentice Hall.

[14] Ireland, R.D., Hoskisson, R.E. and Hitt, M.A. (2009). The management of strategy: Concepts and Cases, $8^{\text {th }}$ Edition, Mason. South-Western Cengage Learning.

[15] Jackson, S. and Philip, G. (2005) Organisational Culture and the Management of Technological Change: A Theoretical Perspective' (2005). ECIS 2005 Proceedings. Paper 149, [Online], Available: http://aisel.aisnet.org/ecis2005/149,_[8 March 2011].

[16] Johnson, G., Scholes, K. and Whittington, R. (2006). Exploring Corporate Strategy. Text and Cases. $7^{\text {th }}$ Enhanced Media Edition, Harlow. Pearson Prentice Hall.

[17] Kaplan, R.S. (2005). How the balanced scorecard complements the McKinsey 7-S model. Strategy and Leadership Journal, vol.33, no.3, pp. 41-46.

[18] Kotter, J. P., \& Heskett, J. L. (1992). Corporate Culture and Performance. New York: Free Press.

[19] Kotter, J.P. (1995). 'Leading Change: Why Transformation Efforts Fail.' Cambridge, MA: Harvard Business Review, March-April, pp. 59-67.

[20] Kotter, J.P and Rathgeber, H. (2006). Our Iceberg Is Melting: Changing and succeeding under any conditions, New York. St. Martin's Press Edition.

[21] Kotter, J.P and Schlesinger, L.A (2008) Choosing strategies for change. Harvard Business Review, vol. 86, no.7/8. JulyAugust, pp. 130, 132-139.

[22] Kuriger, C. (2005). Organisational Change: Case Studies in the Real World. Universal publishers.

[23] Latta, G. F. (2009). Process Model of Organisational Change in Cultural Context (OC3 Model): The Impact of Organisational Culture on Leading Change. Journal of Leadership and Organisational Studies, August, pp.19-37.

[24] Lemmex, S. (2007). Managing Change in Organisations: It's Management's Responsibility, [Online], Available: http:// www.globalknowledge.com [28 March 2011].

[25] Lynch, R. (2000). Corporate Strategy. $2^{\text {nd }}$ Edition, Harlow. Pearson Prentice Hall.

[26] Mannion, R. (2010). Changing Management Cultures and Organisational Performance in the NHS (OC2). Research Report: Produced for the National Institute for Health Research Service Delivery and Organisation Programme. University of Birmingham.

[27] Michalak, J.M. (2010). Cultural Catalysts and Barriers of Copyright (C) 2012, Asian Business Consortium | ABR
Organisational Change Management. A Preliminary Overview. Journal of Intercultural Management vol.2, no. 2, November, pp.26-36.

[28] Mills. J.H., Dye, K. and Mills, A. J. (2009). Understanding Organisational Change. London. Routledge.

[29] Nacinovic, I., Galetic, L. and Cavlek, N. (2009). Corporate Culture and Innovation: Implications for Reward Systems. World Academy of Science, Engineering and Technology 53, pp. 397-402.

[30] Norton, A. (2009). Learning System-Integrated Management. Oxford. CIMA Publications. Oden, H. W. (1997). Managing Corporate Culture, Innovation, and Intrapreneurship. Westport, CT: Quorum Books.

[31] Ojo O. (2009). Impact Assessment of Corporate Culture on Employees Job Performance. Business Intelligent Journal, vol.2, no.2, August, pp. 388-397.

[32] Quinn, R.E., \& Cameron, K.S. (1983). Organizational life cycles and shifting criteria of effectiveness: Some Preliminary evidence. Management Science, 29, 33-51.

[33] Quinn, R.E., \& Hall, R.H. (1983). Environments, organizations, and policymakers: Towards an integrative framework. In R.H. Hall \& R.E. Quinn (Eds.), Organizational theory and public policy. Beverly Hills, CA; Sage.

[34] Rahman, A.W.A. (2002). The influence of Organisational Culture and Strategy on the attitudes towards Organisational Change. Thesis, Degree of Masters of Science. University Putra Malaysia.

[35] Rashid, Z.A., Sambasivan, M. and Rahman, A.A. (2004). The influence of organisational culture on attitudes towards organisational change: Journal of Leadership and organisational development: vol. 25, no 2, pp.161-179.

[36] Simon, J. (2012) The Influence of Corporate Culture on Organizational Change of First National Bank of Namibia, http://uir.unisa.ac.za/bitstream/handle/10500/7653/disserta tion_simon_j.pdf.pdf?sequence=1

[37] Smith L. (2004). Short summary: What Do We Know about Organizational Culture. [Online], Available: http://peoplemanagement.xgsldc.wikispaces.net/file/view/ Aiman- Smith_short_overview_culture.pdf, [28 March 2011].

[38] Saran, A., Serviere, L. and Kalliny, M. (2009). Corporate culture, Organisational Dynamics and Implementation of Innovation: A conceptual framework. Asian Journal of Marketing, 3 (1), pp.10-19.

[39] Schein, E. H. (2004). Organisational Culture and Leadership, $3^{\text {rd }}$ Edition. San Francisco. Jossey-Bass Publishers.

[40] Schein, E. H. (2009). The Corporate Culture Survival Guide. New and Revised Edition. San Francisco. JosseyBass.

[41] Schein, E. H. (2010) Organisational Culture and Leadership, $4^{\text {th }}$ Edition. San Francisco. Jossey-Bass.

[42] Shah, N. (2009). Determinants of Employee Readiness for Organisational Change. A Thesis Submitted for the Degree of Doctor of Philosophy. Brunel Business School, Brunel University.

[43] Shah, N. and Irani, Z. (2010). Examining Employee Attitudes and Behaviours towards Organisational Change 
Using Supervisor and Peer Relations. European, Mediterranean and Middle Eastern Conference on Information Systems 2010 (EMCIS2010) April 12-13 2010, Abu Dhabi, UAE.

[44] Van Stuyvesant Meijen, J. (2007). The influence of organisational culture on organisational commitment at a selected local municipality. A thesis submitted in fulfilment of the requirements for the Degree of Master of Commerce, Department of Management, and Rhodes University.

[45] Zhou-Sivunen, P. (2005). Organisational culture impact in
ERP Implementation in China. M.Sc. Thesis in Accounting. The Swedish School of Economics and Business Administration.

[46] Islam Z.M. (2011), Organizational Culture and Knowledge Sharing: Empirical Evidence from Service Organizations of Bangladesh, African Journal of Business and Management, Vol. 5 (14), pp 5900-5909.

[47] Uddin M.J. (2013), Impact of Organizational Culture on Employee Performance and Productivity: A case study of Telecommunication Sector in Bangladesh, International Journal of Business and Management, Vol. 8, No. 2, 2013 